
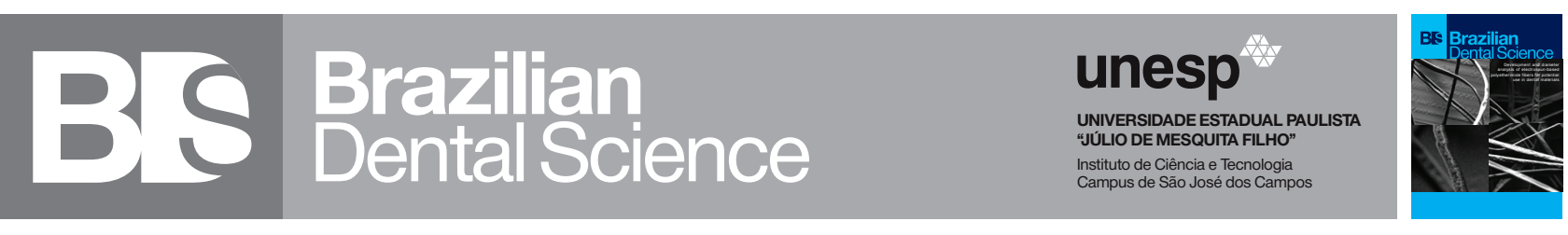

\title{
Student Profile of a Brazilian Public Dental School
}

\author{
O perfil do aluno de uma faculdade de Odontologia pública brasileira
}

Rubens Nisie TANGO$^{1}$, Paula Carolina KOMORI ${ }^{1}$, Luiz Fernando ARAÚJO ${ }^{2}$, Vivian Silveira dos Santos BARDINI ${ }^{3}$, Estela KAMINAGAKURA ${ }^{4}$

1 - Department of Dental Materials and Prosthodontics, Institute of Science and Technology, School of Dentistry, State University of São Paulo (Unesp), Sao Jose dos Campos, Brazil.

2 - Private practice, Sao Jose dos Campos, Brazil.

3 - Department of Environmental Engineering, Institute of Science and Technology, State University of São Paulo (Unesp), Sao Jose dos Campos, Brazil.

4 - Department of Biosciences and Oral Diagnosis, Institute of Science and Technology, School of Dentistry, State University of São Paulo (Unesp), Sao Jose dos Campos, Brazil.

\section{ABSTRACT}

Objetive: The aim of this study was to assess the profile of dental students at the ICT/CSJCUNESP School of Dentistry and their preferred studying style. Material and methods: Data on age, sex, place of residence, first-choice course, secondary education background and study method preference were collected from an online questionnaire given in the second year dental materials course (first class) of the day and evening courses of the years 2016 to 2019. All data were tabulated and submitted to one-way ANOVA and to $t$ test, both with $\alpha=$ 0.05 . Pearson correlation test was performed between demographic data and study method preference $(\alpha=0.05)$. Results: Most of the students were women living in São José dos Campos city who had chosen Dentistry as their first-choice course. Many were originally from other cities and lived in shared accommodation with friends. The majority stated that private high school was their main educational background. The students' age and place of living showed to correlate with study method preference. Conclusion: Although ICT/CSJCUNESP students were from millennial and postmillennial generations, students with public secondary education preferred studying alone, while those from private education preferred studying in group.

\section{KEYWORDS}

Dental students; Dental health education; Formative feedback; Higher education.

\section{RESUMO}

Objetivo: O objetivo do estudo foi o de assessar o perfil de alunos do curso de Odontologia do ICT/ CSJC-UNESP e seu método de estudo de preferência. Material e Métodos: Dados de idade, sexo, local de residência, primeira escolha de curso, formação escolar prévia e método de estudo de preferência foram coletados a partir de um questionário online aplicado no primeiro dia de aula aos alunos do segundo ano na disciplina de materiais odontológicos dos cursos integral e noturno entre 2016 e 2019 . Os dados foram tabulados e submetidos a ANOVA um fator e ao teste $t$, ambos com $\alpha=0,05$. O teste de correlação de Pearson foi realizado para os dados demográficos e métodos de estudo de preferência ( $\alpha$ $=0,05)$. Resultados: A maioria dos estudantes eram mulheres que moravam em São José dos Campos, quem tinham a Odontologia como a primeira escolha de curso. Muitos eram originariamente de outras cidades e compartilhavam moradia com amigos. A maioria relatou ter a escola particular como maior parte no ensino fundamental e médio. A idade do aluno e o local de residência mostraram estar correlacionadas ao método de estudo de preferência. Conclusão: Embora os estudantes do ICT/CSJC-UNESP sejam da geração "millennial" e "pós-millennial", aqueles com formação em escola secundária pública preferiram estudar sozinhos, enquanto que aqueles com formação em escola particular preferiram estudar em grupo.

\section{PALAVRAS-CHAVE}

Estudantes de odontologia; Educação em odontologia; Devolutiva formativa; Ensino superior 


\section{INTRODUCTION}

$\mathrm{T}$ he generation of individuals born between 1981 and 1996, sometimes called 'born digital', digital natives or Millennials and postMillennials ( $\mathrm{Y}$ and $\mathrm{Z}$ generations) have raised a new paradigm related to how they learn. It is usually said that they learn differently when compared to older generations (Babyboomers and Generation-X) [1]. They are very familiar with and can easily access the Internet, computers, tablets, smartphones, and computer software. Previous educational background, interests, and difficulty in discriminating scientific, evidence-based information from general information are factors that influence the search process on the internet. Therefore, learning is not guaranteed [1].

Millennial medical residents in Qatar preferred traditional didactic lectures to blended learning. The authors correlated this result to the educational background of residents, who had graduated from medical schools in the Middle East and Asia based on traditional teaching methodologies [2]. In contrast, some authors reported that implementing new teaching methods which provide information and stimulate connection to students may facilitate their commitment [3-5] and enhance intrinsic motivation [6]. The learning environment, which should consider social, psychological and pedagogical contexts, is another important aspect in the educational process [7-8]. In addition, dental education is considered one of the most stressful educational environments because it requires students to develop communication skills together with academic and clinical competencies [9-11].

Millennials are considered having their brains "wired" to multitask [1], unlike older generations. However, multitasking has been reported to decrease comprehension and attention [1,12-14]. Therefore, this study aimed to explore the educational background and learning environment of new generation students and how they study out of class; in this case, students from the Institute of Science and Technology/ Campus of Sao Jose dos Campos (ICT/CSJC) State University of Sao Paulo (UNESP), 2016 to 2019 dental classes.

\section{MATERIALS AND METHODS}

The responses to a structured online multiple-choice questionnaire, given to second year students using Socrative software (Showbie Inc., Edmonton, $A B$, Canada) in the first class of the Dental Materials course at the School of Dentistry, ICT/CSJC - UNESP in the day and evening courses of 2016 to 2019 were collected and subjected to statistical analysis. This study was submitted to and approved by the Ethical Committee Agency - CAEE 20036919.3.0000.0077. Students were asked to voluntarily respond to six questions using their mobile phones. After each question, the professor provided the students with feedback to the anonymous responses. All data (age, sex, place of residence, first-choice course, secondary education background, and study method preference) were submitted to One-way ANOVA and Tukey's test $(\alpha=0.05)$, except for sex, which was submitted to t test $(\alpha=0.05)$. Pearson correlation test was performed between demographic data and study method preference $(\alpha=0.05)$.

\section{RESULTS}

Table I presents data regarding age, sex, and place of residence and comparisons for each group of data. One-way ANOVA and t test showed significance for each response ( $p<$ 0.003). Table II presents data comparisons about first-choice course, educational background, and study method preference. 
Table I - Data (\%) of age, sex and place of residence

\begin{tabular}{|c|c|c|c|c|c|c|c|c|c|}
\hline \multirow[b]{2}{*}{$\begin{array}{c}\text { Class } \\
\text { (students) }\end{array}$} & \multicolumn{3}{|c|}{ Age } & \multicolumn{2}{|c|}{ Sex } & \multicolumn{4}{|c|}{ Place of residence } \\
\hline & 18 & $19-20$ & $>20$ & M & $\mathbf{F}$ & $\begin{array}{l}\text { In the city, } \\
\text { alone }\end{array}$ & $\begin{array}{l}\text { In the city, } \\
\text { sharing } \\
\text { with friends }\end{array}$ & $\begin{array}{l}\text { In the city, } \\
\text { with } \\
\text { parents }\end{array}$ & $\begin{array}{l}\text { In the city, } \\
\text { with spouse }\end{array}$ \\
\hline 16 - day (49) & 18.4 & 55.1 & 26.5 & 22.5 & 77.5 & 12.2 & 51.0 & 24.5 & 4.1 \\
\hline 16 - evening (33) & 12.1 & 48.5 & 39.4 & 18.2 & 81.8 & 12.2 & 51.0 & 24.5 & 4.1 \\
\hline $17-$ day (46) & 17.4 & 54.3 & 28.3 & 26.1 & 93.9 & 3.0 & 48.5 & 30.3 & 0.0 \\
\hline 17 - evening (29) & 13.8 & 48.3 & 37.9 & 17.2 & 82.8 & 22 & 69.6 & 23.9 & 0.0 \\
\hline $18-\operatorname{day}(48)$ & 20.8 & 50.0 & 29.2 & 22.9 & 77.1 & 6.9 & 34.5 & 24.1 & 6.9 \\
\hline 18 - evening (26) & 19.2 & 42.3 & 38.5 & 42.3 & 57.7 & 27.1 & 52.1 & 14.6 & 2.1 \\
\hline 19 - day (49) & 34.7 & 42.9 & 22.4 & 22.5 & 77.5 & 27.0 & 34.6 & 19.2 & 0.0 \\
\hline 19 - evening (26) & 30.8 & 11.5 & 57.7 & 19.2 & 80.8 & 18.4 & 44.8 & 18.4 & 0.0 \\
\hline Total (306) & $20.9 b$ & $44.1 \mathrm{a}$ & $34.9 \mathrm{ab}$ & $23.9 b$ & $76.1 \mathrm{a}$ & $13.0 \mathrm{bc}$ & $48.1 \mathrm{a}$ & $21.8 \mathrm{~b}$ & $2.6 \mathrm{c}$ \\
\hline
\end{tabular}

Different small case letters in the row, for each data, represent significant difference $(p<0.05)$.

Table I shows that most of the dental students were female and less than 20 years old. Most students lived in the city and had selected Dentistry as their first-choice course (Tables I and II). Many were originally from other cities and lived with friends (Table I). The Pearson test showed a strong positive correlation between students aged 18 years old with the preference of studying alone and alone+group $\left(\mathrm{R}^{2}=0.79\right.$, $\mathrm{p}=0.019 ; \mathrm{R}^{2}=0.81, \mathrm{p}=0.014$, respectively). On contrary, a strong negative correlation was observed between students aged 19-20 years old with the preference of studying alone and alone+ group $\left(R^{2}=-0.89, p=0.003 ; R^{2}=-0.84\right.$, $\mathrm{p}=0.009$, respectively). Regarding to the effect of the place of living, a strong negative correlation was found between students who lived alone and the preference of studying in group $\left(R^{2}=-0.71, p\right.$ $=0.049$ ), whilst a strong positive correlation was found between students who lived with parents and the preference of studying in group $\left(\mathrm{R}^{2}=\right.$ 0.78, $\mathrm{p}=0.021$ ).

Table II - Data (\%) about first-choice course, educational background and study method preference.

\begin{tabular}{|c|c|c|c|c|c|c|c|c|c|c|c|}
\hline \multirow[b]{2}{*}{$\begin{array}{c}\text { Class } \\
\text { (students) }\end{array}$} & \multicolumn{3}{|c|}{ First-choice (\%) } & \multicolumn{4}{|c|}{ Secondary Educational background (\%) } & \multicolumn{4}{|c|}{ Study method preference (\%) } \\
\hline & Dentistry & Medicine & Others & Public & $\begin{array}{c}\text { Public + } \\
\text { prep course }\end{array}$ & $\begin{array}{c}\text { Public + } \\
\text { private }\end{array}$ & Private & $\begin{array}{l}\text { Alone in } \\
\text { silent }\end{array}$ & $\begin{array}{l}\text { Alone doing } \\
\text { something } \\
\text { else }\end{array}$ & $\begin{array}{c}\text { Alone + } \\
\text { group }\end{array}$ & $\begin{array}{c}\text { Group } \\
\text { chat }\end{array}$ \\
\hline 16 - day & 49.0 & 28.6 & 22.4 & 4.1 & 22.5 & 12.2 & 61.2 & 67.4 & 2.0 & 22.4 & 8.2 \\
\hline 16 - evening & 48.5 & 21.2 & 30.3 & 15.2 & 18.2 & 3.0 & 63.6 & 60.6 & 6.1 & 24.2 & 9.1 \\
\hline $17-$ day & 52.2 & 26.1 & 21.7 & 4.4 & 21.7 & 8.7 & 65.2 & 52.2 & 2.2 & 36.9 & 8.7 \\
\hline 17 - evening & 62.1 & 13.8 & 24.1 & 13.8 & 17.2 & 6.9 & 62.1 & 44.8 & 0.0 & 41.4 & 13.8 \\
\hline 18 - day & 45.8 & 20.8 & 33.4 & 8.4 & 35.4 & 10.4 & 45.8 & 60.4 & 2.1 & 37.5 & 0.0 \\
\hline 18 - evening & 57.7 & 34.6 & 7.7 & 19.2 & 26.9 & 11.6 & 42.3 & 53.8 & 3.9 & 42.3 & 0.0 \\
\hline 19-day & 61.2 & 24.5 & 14.3 & 12.2 & 38.8 & 8.2 & 40.8 & 40.8 & 0.0 & 57.2 & 2.0 \\
\hline 19 - evening & 34.6 & 38.5 & 26.9 & 7.7 & 46.2 & 42.3 & 3.8 & 26.9 & 3.9 & 69.2 & 0.0 \\
\hline Total & $51.4 \mathrm{a}$ & $26.0 \mathrm{~b}$ & $22.6 b$ & $10.6 \mathrm{~b}$ & $28.4 \mathrm{~b}$ & $12.9 \mathrm{~b}$ & $48.1 \mathrm{a}$ & $50.9 a$ & $2.5 b$ & $41.4 \mathrm{a}$ & $5.2 b$ \\
\hline
\end{tabular}

Different small case letters in the row, for each data, represent significant difference according to Tukey's test $(p<0.05)$. 
Despite the students had mainly attended private secondary schools and preferred to study alone rather than study in group (Table II), the Pearson correlation test showed that the study method preference is dependent on secondary educational background. A strong positive correlation was observed between students with public/ public+preparation school educational background and the preference of studying alone and alone+group $\left(\mathrm{R}^{2}=0.83, \mathrm{p}\right.$ $=0.010 ; \mathrm{R}^{2}=0.81, \mathrm{p}=0.015$, respectively). Additionally, a strong negative correlation was observed between these group of students and the preference of studying in group $\left(R^{2}=-0.84\right.$, $\mathrm{p}=0.009$ ). Controversially, for the students with private educational background, a strong negative correlation was found for the preference of studying alone and alone+group $\left(R^{2}=-0.90\right.$, $\mathrm{p}=0.003 ; \mathrm{R}^{2}=-0.86, \mathrm{p}=0.006$, respectively). Furthermore, a strong positive correlation was observed between this group of students and the preference of studying in group $\left(\mathrm{R}^{2}=0.74, \mathrm{p}=\right.$ 0.034).

\section{DISCUSSION}

According to the results, $76.1 \%$ of students were women (Table I), which was similar to the percentage reported by Orsini et al. in 2018 (63\%) [15], but not the percentage reported by AlQahtani et al. (2018), who reported $73.1 \%$ men [16]. The difference in male to female proportion influenced learning style preferences [15], empathy and stress levels [11,17-21], and vulnerability to burnouts $[6,22]$. Being married also heightened the sensitivity of students to stressful experiences [23-24].

Brazilian federal public universities, as well as some São Paulo State public universities such as ICT/CSJC-UNESP, currently run affirmative actions (quotas) by reserving $50 \%$ of openings in the entry examinations for students with a secondary public education background, who come from a poor social-economic family, and who self-declare as black, mulatto or Indian. Quota students from poor families could face two disadvantages: the inability to pay for instruments and to maintain themselves, and the anxiety that brings. In the present study, although there was no assessment of quota, a trend of increasing entry of students with public secondary education background can be observed. Thus, with the maintenance of the quota policy, future studies should be performed.

Students preferred to study alone and in silence before going into study groups (Table II). However, as seen in the results of Pearson correlation tests, students with different educational background showed distinct study preference. Students with public educational background preferred to study alone while those with private educational background preferred studying in group. Thus, educational background may have played an important role in their outof-class study method preference.

The fact that most of the students were not married and lived in the city sharing accommodation with friends (Table I) could facilitate out-of-class studying because they did not have to spend time travelling home or have household care issues, i. e., they had time to support each other and to share individual experiences. In this scenario, it was interesting to observe a strong negative correlation between students who lived alone and the preference of studying in group and a strong positive correlation between students who lived with parents and the preference of studying in group. Professor asked students to support each other not only educationally but also emotionally, since most were out of the parental home.

Despite news accounts that Generation $\mathrm{Z}$ attention spans have shrunk to eight seconds and that they are allegedly unable to focus for extended periods of time [25], the present study showed they do not like studying while listening to music or watching TV. Furthermore, as seen 
in the present study the study method preference changes with students'age. There was a strong positive correlation between students aged 18 years old with the preference of studying alone and alone + group, while a strong negative correlation was observed between students aged 19-20 years old with the preference of studying alone and alone+group. The literature has already shown that multitasking, and switching between tasks with high frequency hinders comprehension and impedes attention [1,12-14]. During the questionnaire feedback, the professor was able to ask students to perceive how they as individuals learn and which metacognitive strategies they use to improve self-regulated learning.

The fact that Dentistry was the first choice of the majority of students is important for motivation [26]. This is also true for those who chose Medicine, since they reported taking care of human beings as the main motivation. The high percentage of students who had Medical School as their first choice was because the entry examinations are the most competitive in Brazil. The motivational or affective dimensions of the educational process can influence student learning behavior [20-21,27-31]. In this sense, the application of the questionnaire to the firstday class was a positive aspect of this study as it used a more humanized professor-student approach [16]. The feedback of questionnaire was important to give students time to understand their sense of belonging [32] and to discuss and share individual experiences of dealing with the challenges of short- and long-term goals during their dental education. Students reported that professors' empathy and sharing online social media apps with them facilitated their educational engagement. It has been reported that millennial and post-millennial students consider a more humanized professor-student approach as an important aspect of their years in school $[4-5,16,26]$.

Limitations of the present study include that the students were not asked about cognitive learning or about their learning preferences (monomodal or multimodal learning). Additionally, no questionnaires were distributed at the end of the courses to verify possible modifications to student study style preference. Professors should provide information using different approaches, with a focus on out-ofclass study, so that students can choose, which are better suited to their individual cognitive learning style [5,15-16,33-34]. This is especially important when considering Dentistry as a health science course in which students should have empathy for their patients in addition to acquiring professional skills. Furthermore, professionals of higher education, especially those in the health sciences, should be aware of their students' learning environment and talk to them about strategies to facilitate the learning process.

\section{CONCLUSION}

Limited by the results of this study, the following conclusions were drawn:

1 - ICT/CSJC-UNESP dental students were mainly female under 20 years old, who chose Dentistry or Medicine as their first-choice course. There was a positive correlation between students aged 18 years old with the preference of studying alone and alone+group, and a negative correlation between students students aged 1920 years old with the preference of studying alone and alone+ group.

2 - They mainly lived in the city sharing their accommodation with friends. There was negative correlation between students who lived alone and the preference of studying in group, while a strong positive correlation was found between students who lived with parents and the preference of studying in group.

3 - Their educational background was mainly in private high schools. Although ICT/ CSJC-UNESP dental students of 2016 to 2019 classes were of the millennial and post-millennial 
generations, students with public secondary education preferred studying alone, while those from private education preferred studying in group.

\section{Conflict of interest}

Authors declare no conflict of interest.

\section{Acknowledgments}

None to declare.

\section{Funding}

None to declare.

\section{Regulatory Statement}

This study was conducted in accordance with all the provisions of the local human subjects oversight committee guidelines and policies of: ICT/CSJC - UNESP Ethical Committee Agency. The approval code for this study is: CAEE 20036919.3.0000.0077.

\section{REFERENCES}

1. Behar-Horenstein LS, Horvath Z. Generational learning differences in today's dental students: a popular myth. J DentEduc. 2016;80(5):588-94.

2. Bashir K, Farook KS, Thomas SH. The learning preferences of millennial emergency medicine residents in Qatar. Int J Med Educ. 2019;27(10):136-7. doi: 10.5116/ime.5dib.ae92.

3. Evans C, Vermunt JD. Styles, approaches, and patterns in student learning. Br J Educ Psychol. 2013;83(2):185-95. doi:10.1111/bjep.12017.

4. Cameron EA, Pagnattaro MA. Beyond millennials: engaging generation Z in business law classes. J Legal Stud Educ. 2017;34(2):317-24. doi: 10.1111/ jlse.12064.

5. Chicca J, Shellenbarger T. Generation Z: approaches and teaching-learning practices for nursing professional development practitioners. J Nurses Prof Dev. 2018;34(5):250-6. doi: 10.1097/NND.0000000000000478.

6. Chaudhuri JD. Stimulating intrinsic motivation in millennial students: a new generation, a new approach. Anat Sci Educ. 2020;13(2):250-71. doi: 10.1002/ ase.1884.

7. Lizzio A, Wilson K, Simons R. University students' perceptions of the learning environment and academic outcomes: implications for theory and practice. Stud High Educ. 2002;27(1):27-52. doi: 10.1080/03075070120099359.

8. Suksudaj N, Lekkas D, Kaidonis J, Townsend GC, Winning TA. Features of an effective operative dentistry learning environment: students' perceptions and relationship with performance. Eur J Dent Educ. 2015;19(1):53-62. doi: 10.1111/eje.12102

9. Brondani MA, Ramanula D, Pattanaporn K. Tackling stress management, addiction, and suicide prevention in a predoctoral dental curriculum. J Dent Educ. 2014;78(9):1286-93.
10. Crego A, Carrillo-Diaz M, Armfield JM, Romero M. Stress and academic performance in dental students: the role of coping strategies and examination-related self-efficacy.J Dent Educ. 2016;80(2):165-72.

11. Alhaji MN, Khader Y,Murad AH, Celebic A, Halboub E, Márquez JR, et al. Perceived sources of stress amongst dental students: a multicountry study. Eur J DentEduc. 2018;22(4):258-71. doi: 10.1111/eje.12350

12. Pea R, Nass C, Meheula L, Rance M, Kumar A, Bamford H, et al. Media use face-to-face communication, media multi-tasking, and social well-being among 8- to 12-year-old girls. Dev Psychol. 2012;48(2):327-36. doi: 10.1037/ a0027030.

13. Ophir E, Nass C, Wagner AD. Cognitive control in media multitaskers. Proc Nat Acad Sci USA. 2009;106(37):15583-7.

14. Patoine B. Brain development in a hyper-tech world. 2008

15. Orsini C, Binnie V, Wilson S, Villegas MJ. Learning climate and feedback as predictors of dental students' self-determined motivation: the mediating role of basic psychological needs satisfaction. Eur J Dent Educ. 2018:22(2):e228-e236. doi: 10.1111/eje.12277.

16. AlQahtani N, AlMoammar K, Taher S, AIBarakati S, AlKofide E. Learning preferences among dental students using the VARK questionnaire: a comparison between different academic levels and gender. J Pak Med Assoc. 2018;68(1):59-64.

17. Lambert RF, Wong CA, Woodmansey KF, Rowland B, Horne SO, Seymour BA. National survey of U.S. dental students' experiences with international service trips. J DentEduc. 2018;82(4):366-72. doi: 10.21815/JDE.018.036.

18. Liao PC, Chen SK, Lin SS. Latent profiles of stress and their relationships with depression and problematic Internet use among college freshmen. Scand J Psychol. 2018;59(6):621-30. doi: 10.1111/sjop.12489.

19. Dyrbye LN, Sciolla AF, Dekhtyar M, Rajasekaran S, Allgood JA, Rea M, Knight AP, Haywood A, Smith S, Stephens MB. Medical school strategies to address student well-being: a national survey. Acad Med. 2019;94(6):861-8. doi: 10.1097/ACM.0000000000002611.

20. Burgos CM, Josephson A. Gender differences in the learning and teaching of surgery: a literature review. Int J Med Educ. 2014;15(5):110-24. doi: 10.5116/ ijme.5380.ca6b.

21. Batenburg V, Smal J, Lodder A, De Melker R. Are professional attitudes related to gender and medical specialty? Med Educ. 1999;33(7):489-492. doi: 10.1046/j.1365-2923.1999.00333.x.

22. McLuckie A, Matheson KM, Landers AL, Landine J, Novick J, Barrett T, et al. The relationship between psychological distress and perception of emotional support in medical students and residents and implications for educational institutions. Acad Psychiatry 2018;42(1):41-7. doi: 10.1007/ s40596-017-0800-7.

23. Robles J, Cox CD, Seifert CF. The impact of preceptor and student learning styles on experiential performance measures. Am J Pharm Educ. 2012;76(7):128. doi: 10.5688/ajpe767128.

24. DeWittD, Canny BJ, Nitzberg M, Choudri J, Porter S. Medical student satisfaction, coping and burnout in direct-entry versus graduate-entry programmes. Med Educ. 2016;50(6):637-45. doi: 10.1111/medu.12971

25. Fastcompany [Internet] [cited 2019 Sep 20]. Finch J. What is generation Z, and what does It want?. Available from: https://www.fastcompany. com/3045317/what-is-generation-z-and-what-does-it-want.

26. da Graça Kfouri M, Moysés ST, Gabardo MCL, Moysés SJ. Gender differences in dental students' professional expectations and attitudes: a qualitative study. Br Dent J. 2017;22(6);441-5. doi:10.1038/sj.bdj.2017.810. 
27. Campos-Sánchez A, López-Núñez JA, Carriel V, Martín-Piedra MÁ, Sola T, Alaminos M. Motivational component profiles in university students learning histology: a comparative study between genders and different health science curricula. BMC Med Educ. 2014;10(14):44-6. doi: 10.1186/1472-6920$14-46$.

28. Simpkins SD, Davis-Kean PE, Eccles JS. Math and science motivation: a longitudinal examination of the links between choices and beliefs. Dev Psychol. 2006;42(1):70-83. doi:10.1037/0012-1649.42.1.70.

29. Glynn SM, Brickman P, Armstrong N, Taasoobshirazi G. Science motivation questionnaire ll: validation with science majors and nonscience majors. J Res Sci Teach. 2011;48(10):1159-76. doi: 10.1002/tea.20442.

30. Mazlo J, Dormedy D, Neimoth-Anderson JD, Urlacher T, Carson GA, Kelter PB. Assessment of motivational methods in the general chemistry laboratory. J Coll Sci Teach 2002;31(5):318-21.
31. Lin YG, McKeachie WJ, Kim YC. College student intrinsic and/or extrinsic motivation and learning. Learn Individ Differ. 2003;13(3):251-8.

32. Bowman $\mathrm{M}$. The transition to self-regulated learning for first-year dental students: threshold concepts. Eur J DentEduc. 2017;21(3):142-50. doi: 10.1111/ eje.12193.

33. Good JP; Ramos D; D'Amore DC. Learning style preferences and academic success of preclinical allied health students. J Allied Health. 2013;42(4):e8190.

34. Hampton D, Welsh D, Wiggins AT. Learning preferences and engagement level of generation z nursing students. Nurse Educ. 2020;45(3):160-4. doi: 10.1097/NNE.0000000000000710.

\section{Rubens Nisie Tango}

(Corresponding address)

Department of Dental Materials and Prosthodontics, Institute of Science and Technology,

State University of São Paulo (Unesp), Av. Eng. Francisco Jose Longo, 777, 12245-200,

Sao Jose dos Campos, SP, Brazil,

Email: rn.tango@unesp.br. 